\title{
The Study of Buddhism in Sri Lanka: Issues, Challenges and Prospects ${ }^{1}$
}

\author{
Asanga Tilakaratne \\ Emeritus Professor of Buddhist Studies, Department of Pali and Buddhist Studies, \\ University of Colombo
}

\section{KEYWORDS:}

Buddhist Studies, Pali Studies, the academic study of Buddhism, textual study, learning, practice.

Suggested Citation: Tilakaratne, A. (2021). The study of Buddhism in Sri Lanka: Issues, challenges and prospects. University of Colombo Review (New Series III), 2(1), 17 - 28.

(c) 2021 The Authors. This work is licenced under a Creative Commons Attribution 4.0 International Licence which permits unrestricted use, distribution, and reproduction in any medium, provided the original work is properly cited. 


\section{Introduction}

In Sri Lanka, Buddhism is taught from elementary to secondary school, a period of thirteen years altogether. Not considered a difficult subject to master, many students score well in the examinations. In a country where most of the population identify with one religion or another, Buddhists comprise almost $70 \%$ of the population. Buddhism is popular, therefore, as a school subject. There are also Dhamma schools, around ten thousand altogether, held on weekends. Usually held at Buddhist monasteries, they attract about two million students altogether. Both these types of schools appear to do good work in imparting subject knowledge to their participants, although there is no objective method to measure their influence on the participants' lives. Apart from these two categories of schools, there are pirivenas, numbering almost seven hundred, meant for novice Buddhist monks (and a relatively small number of lay students) where Buddhism is, naturally, the central subject.

In the field of higher education, the major Sri Lankan universities teach Buddhist studies and related subjects, and usually attract a good number of undergraduates. In addition, there are two state-run universities focusing exclusively on Buddhist studies and several private colleges specializing in various aspects of the discipline. These universities have postgraduate programs that attract several hundred students, both local and foreign - the latter mostly from Southeast and East Asian countries. Each of these programs have their own issues and challenges in addition to questions on the practical value of Buddhist Studies education.

\section{History and Character of Buddhist Studies in Sri Lanka}

Buddhist studies is one of the oldest fields of study in the world. A phenomenon close to what we consider today as academic studies seems to have started in Buddhism from the time of the Buddha himself, and there is evidence that right after the parinirvana (passing away) of the Buddha, the study of his teachings started out of the need for its preservation for posterity. Buddhism being first and foremost a soteriological system meant to be followed by those whose intent is to make an end to suffering by realizing nirvana, the emphasis was not so much on academic learning, as mastering it to the extent one needs it for one's practice. Learning without practice was discouraged, and the emphasis was on knowing the Dhamma only insofar as one needed it for practice. ${ }^{2}$ At the same time, however, the need for preserving the Dhamma was felt by the leading followers of the Buddha during his lifetime itself. This was felt more acutely when the Buddha attained parinirvana, naming none to replace him as the teacher. This made it necessary for the senior followers to arrange the Dhamma methodically and assign groups of the monastic community headed by senior monastic leaders to keep the Dhamma in their memory, in order to transmit it to future generations of their students.

The accounts of the first council, held after three months of the passing away of the Buddha, record the measures adopted at this meeting for the preservation of the Dhamma. This gathering can be considered the commencement of academic studies in Buddhism, 
for it marks the beginning of the study of the Dhamma for a purpose other than one's own soteriological goal, namely, to help others to realize their own soteriological goals, which was an equally lofty goal. This necessitated the monks memorizing the texts and interpreting what was memorized. In addition to the texts, the tradition of interpretation of them became established and was transmitted along with the texts themselves. It is this tradition of memorizing and interpreting the teaching that was brought to Sri Lanka by Arahant Mahinda in the 3rd Century BCE.

It appears that the Theravada academic tradition gradually became established in the island thanks to the efforts of the members of Arahant Mahinda's group and (most probably) the subsequent early visitors from the Indian mainland. There is a story in the Commentary to the Vinaya on how Arahant Mahinda established the tradition in the country and made it a truly indigenous one. ${ }^{3}$ At the very early stage of his activities on the island, Arahant Mahinda is reported to have said to the king that, in order for the Sasana (Buddha's religion) to become established in the country, he must allocate a sima, a specially designated location with fixed boundaries for the conduct of monastic legal activities in his kingdom. The king, having done so, asked Arahant Mahinda whether the Sasana has now been established in the country. The monk responded to the ruler saying that although it is now established, it has yet to take root in the country. To the king who inquired as to how the Sasana will take root, the Arahant Mahinda said that the Sasana will do so in the country on the day a person from this country enters monkhood, masters the vinaya-pitaka (basket of discipline) and teaches it to others. This was fulfilled by Arittha, a member of the royal family. The reference to the basket of Vinaya may be taken as signifying the practice of the monastic way of life, while the reference to mastering it signifies the academic aspect. The story can be understood as signifying the birth of an indigenous tradition of Buddhism in the country, with its characteristic mark of blending theory with practice.

It is a basic Buddhist insight that learning without virtue is of no use. There is evidence which suggests that the tradition was ever conscious of this insight and tried hard to preserve this spirit, even amidst setbacks. A turning point was the period of Vattagamini Abhaya, during whose reign the monks committed the word of the Buddha into writing. The immediate event that precipitated this development was the long famine the country suffered, during which many monks who maintained the texts in their memory died of starvation. While some monks left for India to save their lives, there were others who opted to stay and maintain the Dhamma in their memory. When finally, the famine of fourteen years ended, those who left for India returned, and the first thing the two groups did was to compare their memories. To their utter relief, they found that their memories corroborated with each other. Nevertheless, this event highlighted the risk in preserving the vast literature of the Dhamma only in memory. There was also another incident, albeit of a somewhat different nature, highlighting the same risk. One of the texts, "Niddesa" (belonging to the Khuddaka-nikaya, the fifth collection of the basket of discourses) was preserved in the memory of a single person, of whose moral integrity the other monks were not certain. Consequently, they were reluctant to go to him, pay respect, and learn the text from him which, anyhow, they had to do. 
Amidst these developments, there arose among the monks a debate as to which was the root of the Sasana, learning or practice (pariyatti or patipatti). ${ }^{4}$ In this debate those who represented the practice argued that theirs was the root. Those who represented learning, counter-argued that the Dhamma could not be practised without knowing what it was. The learners won the battle over those who practised insight meditation (vipassanadhura), wore rag robes (pansukulika) and stayed in the forest (arannavasi), thus paving the way for a tradition of those who learned the Dhamma (ganthdhura = yoke of books) and stayed in cities (gamavasi) teaching the doctrine to others (dhamma-kathika). In the subsequent Buddhist tradition of the country, these two sets of characteristics were identified as representing two ways of monastic life, i.e., practitioners and learners, the former considered less important than the latter. E. W. Adikaram who did a thorough study of these developments states the following:

The change of attitude, though no attention has been paid to it in the commentaries, is of the utmost importance in the history of Theravada Buddhism. This school of Buddhism claims its descent from Upali, the greatest vinayadhara [expert in discipline] among the disciples of the Buddha. Mahinda, too, the founder of this school in Ceylon, insisted on the reciting of the Vinaya, by a Ceylonese bhikkhu as it was only then, he maintained, that the sasana would take root in Ceylon. Mahinda's Buddhism was a religion predominantly of practice, and the victory mentioned above, of suttanta [discourses or doctrine] over Vinaya would not have been one after the heart of that great missionary. (2009, p. 78)

Although this division has persisted in Sri Lankan Buddhist history, to some extent even up to date, practice has not lost its validity and even its relative superiority among the learners. The Visuddhimagga Buddhaghosa refers to an episode between Maha Buddharakkhita, who was a great learner, and Tipitaka Cula Abhaya, who was a practitioner in addition to being well versed in all three baskets. When the latter struck the golden bell of the Great Monastery (Mahavihara of Anuradhapura) announcing his willingness to teach the doctrine, the resident monks were reluctant to listen to him, saying that what he taught was not in accordance with their teachers of the Great Monastery. When the matter was referred to the head of the monastery, Cula Abhaya was asked to go to Maha Buddharakkhita and learn texts from him. The latter did so accordingly, and at the completion of his study something strange happened: the teacher sat down on a mat before Cula Abhaya to whom he explained the doctrine and asked him to guide him in meditation. Cula Abhaya responded by saying: "What are you saying, venerable sir? Have I not heard it all from you? What can I explain to you that you do not already know?" To this, Maha Buddharakkhita's response is revealing: "This path is different for one who has actually traveled by it" (Nanamoli, 1956, p. 98). This story reported by Buddhaghosa, who himself was the most outstanding example of learning in the Theravada tradition and who compiled his commentarial works about five centuries after the texts were committed to writing, clearly places practice above learning. Judging by the high esteem accorded even today by monks and lay people alike in Sri Lanka to those who dwell in forests in meditation, we can see that this emphasis still remains. 


\section{Decline, Revival and Recent Developments}

The Buddhist academic tradition continued in the country without serious disruption till the arrival of Europeans in the 16th Century (1505). Buddhism, which was already showing signs of decay by the end of the 15th Century, suffered immensely under colonial rule. The subsequent two centuries under the Portuguese mark the lowest point of the Buddhist tradition in the country. This does not mean, however, that Buddhist studies disappeared completely during this period. In an atmosphere in which Buddhists had to fight for their very survival, there were, naturally, no properly functioning monasteries let alone centers of learning. But the credit should go to the "in-between" group of Ganinnanse, who were neither fully household nor fully monastic, for making sure that the Buddhist texts and other Buddhist artifacts were physically protected.

The revival of Buddhism owes its origin to Velivita Saranankara Thera (1698-1778), later appointed by the king as sangha-raja (ruler of the Sangha), who had to revive not only the Buddhist academic tradition but also the monastic tradition which was similarly in decline. In this article, I will not focus on the monastic tradition, although it was a precondition for the revival of the academic tradition. Velivita Saranankara had to rediscover both these traditions from scratch. Academic study was at such a low state that, it is said, he could not find anyone to learn the basics of the Pali language. Finally, he had to get help from a nobleman who had been condemned by the king and was awaiting execution. But even his guidance was elementary. The rest Velivita Saranankara had to discover himself, without guidance from a teacher. His efforts became gradually successful when he gathered a group of like-minded followers and initiated community learning. He received further support in his endeavors from the monks who were brought from Siam (Thailand) for the purpose of re-establishing "higher admission" (upasampada) among the Sri Lankan Sangha. The key feature of his academic revival was that, while it helped spread the learning of the Pali language in which the Buddhist texts were written, it also facilitated the compilation of Sinhala translations of these texts. By the time Velivita Saranankara passed away, he had put the Buddhist tradition back on track with a group of learned and virtuous monks. ${ }^{5}$ It is this revival that continued through the nineteenth century with the two centres of Buddhist learning, Vidyodaya Pirivena (established in 1873 by Hikkaduve Sumangala Thera) and Vidyalankara Pirivena (established in 1875 by Ratmalane Dharmarama Thera). ${ }^{6}$

\section{Modern Buddhist Studies}

From the pre-modern period to the beginning of the 20th Century, the study of Buddhism was almost exclusively textual, through which knowledge of the Dhamma (doctrine of the Buddha) was obtained for the purpose of one's own religious edification as well as for teaching it to others by way of formal teaching, delivering dhamma sermons or imparting meditation instruction. The study of Buddhism away from traditional textual study is a phenomenon that started with modern academic studies, introduced to Sri Lanka (then Ceylon) toward the end of the British colonial period with the establishment of the University of Ceylon in 1942 which succeeded Ceylon University College that began in 
1921, where Pali and Sanskrit were taught in the same manner as Latin and Greek were taught at western universities.

K. N. Jayatilleke (1920-1970) who studied Pali and Sanskrit at Ceylon University College from 1939 to 1942 later became the leading Buddhist philosopher in the country. Once the University of Ceylon was established, a separate department for Pali was started, and G. P. Malalasekera (1899-1973), another would-be leading Buddhist scholar of the country, became its first head. In 1952, the university was shifted to Peradeniya. It is there that Buddhist Civilization was added to the Pali department, which today has evolved into the Department of Pali and Buddhist Studies.

As the only way to study Pali is through the Buddhist texts, it is natural that Pali Studies is inseparably tied to Buddhist Studies. In Sri Lanka, Pali marks an early stage of Buddhist Studies in the modern academic sense. Those who studied Pali as a subject either for the General or Honors degree, were English-educated lay (non-monastic) students. A few of them went onto graduate studies and were absorbed into university academic positions, but most went into either school teaching or joined the government civil sevice. Today, Pali is still taught as a subject at universities and the majority of students are Buddhist monks. The subject includes a Buddhist conceptual/philosophical aspect along with linguistic and literary approaches, which makes it still relevant to Buddhist doctrinal/ philosophical studies today.

The study of the Sanskrit language, which was an important characteristic of traditional local scholarship should also be noted. At the universities, along with Pali, Sanskrit is taught from elementary to advanced level. Again, almost all students following this subject are monastic. The significance of Sanskrit is that although Buddhist studies in the country are focused on Theravada, studies in Mahayana and other Buddhist schools which have their literature in Sanskrit are not neglected.

Another aspect of Buddhist/Pali and Buddhist Studies is Abhidhamma (Sanskrit: Abhidharma), which is called "the higher doctrine", and is contained in the third section of the Pali canon. In the field of Buddhist Studies, Abhidhamma is usually called "philosophy" in the sense that it deals with what is considered to be the ultimate reality which provides the basis for experienced reality. This, in Abhidhamma terminology, is constructed phenomena. It may also be described as philosophy in a sense closer to the modern sense of the term, for it has developed its own precise language and methods of analysis. Abhidhamma basically consists of definition, analysis, classification, and categorization of the dhammas, a broad term which includes not only the entirety of the teachings of the Buddha, but also all constructed and unconstructed phenomena. Logical methods such as distribution and conversion of terms have been used in this literature. Included in Pali studies programs at universities are several courses in Abhidhamma taught at varying depth. Compared, however, to the practice in a country like Myanmar, where Abhidhamma occupies a central part of the curriculum and is memorized and studied in a traditional manner consulting commentaries and sub-commentaries, Sri Lankan university studies in Abhidhamma remain introductory. Unlike Myanmar, Sri Lanka does not have a widespread tradition of monastic Abhidhamma studies either. 
Another discipline under which Buddhist Studies is taught is philosophy. The Department of Philosophy at the University of Ceylon based in Colombo was started in 1950 and shifted to Peradeniya in 1952. The first head of department was T. R. V. Murti, an Indian national who specialized in Buddhist, Vedanta, and Kantian philosophies, and who wrote the well-known work The Central Philosophy of Buddhism (1956), a comparative study of the Madhyamaka system and Kantian philosophy. Murti left after two years, and K. N. Jayatilleke became the head of the department in 1964 until his untimely death in 1970.

Jayatilleke studied at Cambridge University and had the privilege of being admitted to Wittgenstein's classes, held in his private quarters in Whewell's Courts at Trinity College, from 1945 to 1947 (Jayatilleke, 1963, p. 10). Jayatilleke's work, Early Buddhist Theory of Knowledge (1963), hailed as a "masterpiece by any standard", 7 showed his orientation as an analytical philosopher who defended an empiricist interpretation of early Buddhist (by which he meant Pali canonical Buddhist) philosophy. The Department of Philosophy at the University of Peradeniya became, under the influence of Jayatilleke, a center for Buddhist philosophical studies.

The scholars produced under Jayatilleke's influence and guidance, had expertise in both Western and Buddhist philosophies. D. J. Kalupahana (1936-2014, who later moved to the University of Hawaii's Department of Philosophy), R. D. Gunaratne (b. 1937), Padmasiri de Silva (b. 1933), Gunapala Dharmasiri (1940-2015), P. D. Premasiri (b. 1941) and A. D. P. Kalansuriya (1937-2011), all of whom taught at Peradeniya, had this comparative expertise on Buddhist and Western philosophies. This is a by-gone era of Buddhist philosophy not only at Peradeniya but also in the whole country. This is because the Buddhist philosophical orientation that Peradeniya had, was missing at other university departments of philosophy which were also of more recent origin. ${ }^{8}$

\section{Mainstreaming Buddhist Studies}

Buddhist studies became an important feature of the university curriculum in Sri Lanka with the start of the Vidyodaya and Vidyalankara Universities in 1959 - the result of an upgrade to university status of the two leading traditional Buddhist monastic education centers of the country, Vidyodaya Pirivena and Vidyalankara Pirivena. ${ }^{9}$ In these universities, unlike at the University of Ceylon and the University of Peradeniya at the beginning, the medium of instruction was Sinhala, the local language of the majority Sinhala community. This allowed access to modern education for a larger, non-English-speaking group. Departments of Buddhist studies were formed where not only the Pali language but also the Sanskrit language and textual studies, as well as new subjects such as Buddhist Culture and Buddhist Philosophy were taught. Buddhist Studies is also taught at the Universities of Ruhuna and Colombo. At the University of Colombo, as in other universities, the subject is taught as a three-year general and a four-year special/honors degree program, and there are two streams for students to choose from: Buddhist Culture and Buddhist Philosophy. In the latter, in addition to courses on subjects related to Buddhist philosophy such as Buddhist 
logic, epistemology, and ethics, two survey courses on Indian and Western philosophies are also offered.

In addition to the above universities that are under the purview of the University Grants Commission, there are two other universities under the ambit of the Ministry of Higher Education which teach Buddhist Studies, namely the Bhiksu University of Sri Lanka (started in 1969, open only to the Buddhist monastic community and located in the ancient city of Anuradhapura), and the Buddhist and Pali University (started in 1982, located in Homagama, in the suburbs of Colombo). Graduate studies in Buddhism are conducted in both English and Sinhala media in all departments at these two universities. The Postgraduate Institute of Pali and Buddhist Studies, attached to the University of Kelaniya but which operates independently, also specializes in Buddhist Studies, including Buddhist textual, cultural, and philosophical studies at graduate level. At this institute, and all the other departments where the subject is taught, graduate studies are conducted as a course-work Master's degree of one or two years' duration, while research-based MPhils and $\mathrm{PhDs}$ take longer.

A typical undergraduate student who chooses Buddhist Studies is mostly a Buddhist monastic member or a lay student who studies Buddhism as one of his/her three first-year subjects. With their Buddhist religious background, students seem to think that they can secure a better grade in Buddhist studies, enabling them to move on to a subject they wish to specialize in, from the second year onwards. Those who opt for, or qualify to follow a four-year degree in Buddhist Studies are relatively few, and the majority of them are young members of the Buddhist Sangha. Those who study Pali (and Sanskrit) are almost all members of the Sangha. Those who complete the three-year degree are mostly absorbed as teachers into the government school system where religion is a compulsory subject. A few among those who follow the four-year program in Buddhist studies have openings, if they are lucky, in the university system as lecturers.

The Master's degree programs in Buddhist studies by course-work, conducted in the Sinhala medium at universities, are very popular, again mostly among government school-teachers who can use this qualification for promotion in their careers. Englishmedium Master's degree programs by course-work are popular among foreign students, in particular, among those from Southeast Asian countries and Buddhist monastic students from Myanmar. In addition, there are mature students from various professions and walks of life who choose to study Buddhism not necessarily for professional requirements but for the sake of knowledge and/or interest in religion. A good number of candidates in this category follow courses in the English medium. Of these students, the number who proceed to conduct research in Buddhist Studies is slim. An exception is at the Postgraduate Institute of Pali and Buddhist Studies, where dozens of foreign students, again mostly monastic members, pursue higher research degrees along with a smaller number of Sri Lankan students.

For the reason that Buddhist Studies is taught mostly at state universities and institutions, ${ }^{10}$ academic career opportunities for students in the field are limited and hence 
extremely competitive. Those who are successful and hired, persue graduate studies in India or China, unlike previously, when all would-be Buddhist scholars followed graduate studies in the UK and subsequently in the USA, Canada, or Australia (e.g., the "Peradeniya school"). They choose India for both economic and academic reasons, and China mainly for the financial support available for their studies. Graduate studies in Japan, Hong Kong or any European country almost totally depend on financial assistance, and since such assistance is hard to come by, the number of students going to these countries is decreasing.

During the last century, Sri Lankan Buddhist scholars had a reputation for comparative philosophical knowledge because they had their training in Western philosophical or religious departments. The fact that most of them completed their undergraduate studies in the English medium was helpful for their further study in different academic environments. Today, one cannot say the same about the English proficiency of would-be university teachers in Buddhist studies, which is another reason why they look for opportunities in non-English speaking countries. Owing to this shift in the location of their studies, however, one has to expect them to adopt different approaches to Buddhist studies and to have expertise in different areas of the subject. These changes are neither good nor bad in themselves: much depends on not what they study but how they pursue their study of Buddhism.

\section{Conclusion}

As we found in the preceding discussion, the study of the teaching of the Buddha (from which Buddhist Studies as an academic discipline evolved), had, from its very inception, an equal emphasis on both theory and practice. If theory without practice was empty, practice without theory was considered blind. This trend has continued in the Sri Lanka tradition albeit with debates and controversies. It is this same tradition that was revived by Saranankara Sangharaja, marking the modern revival of Buddhism as well as Buddhist Studies. The key element in this tradition was the study of texts, which was considered the best way to know what the Buddha taught as a total system leading to the final goal of realizing nirvana. Recent examples of such textual erudition are the edition of Pali commentaries sponsored by the family of Munasinghe Hewavitarna (Anagarika Dharmapala's younger brother), edited by leading scholar monks of the country at the turn of the 20th Century, and the Sinhala translation of the Pali Tripitaka sponsored by the Sri Lanka government in order to mark the 2500th Buddha Jayanti and translated by leading Sri Lankan scholar-monks belonging to the middle period of the last century. The erudite monks who executed these two projects belong to the pre-university period of Buddhist Studies in Sri Lanka. They received their education from their monastic teachers in monastic settings. For these monks, the study of texts was a way of life and not part of a disinterested academic pursuit. Today, however, with the arrival of the university system, Buddhist Studies is pursued like any other subject, mainly for the sake of gathering knowledge aimed at better prospects of a livelihood. For this purpose, it has become just another subject: popular, as mentioned at the beginning of this discussion, from early school education to postgraduate studies, but devoid of much existential relevance. 
It is not reasonable, however, to blame the modern university system exclusively for these failures. What is to be blamed, if at all, is the instrumentalist attitude towards education within which Buddhist Studies too is included, shedding its meaning and relevance for life. Education as a means of livelihood is a practical need and cannot be ignored. But a subject like Buddhist Studies in a context like Sri Lanka should not be just one subject among many. It has to be taught in such a way that its essence is not lost. Delivering the Buddha Jayanti lecture in 1969 in India, K. N. Jayatilleke (1978/2009) stated the following:

In my opinion the philosophy of the Buddha presents a challenge to the modern mind and it should be a primary function and duty of modern philosophers to examine its solutions to basic questions.

In his own academic practice, Jayatilleke strived to do what he advocated here. His published works as well as his religious and social activities bear testimony to his conviction. As already discussed, there was a whole group of philosophers from his department at the University of Peradeniya who were inspired by his ideas and practices. But that generation of scholars is fast disappearing. The issue, therefore, is not with traditional versus modern studies of Buddhism. What Buddhist scholars like K. N. Jayatilleke showed is that in order to be a Buddhist scholar today, capable of meeting the challenges of the globalized world, one needs to be equipped not only with traditional languages such as Pali but also with modern languages of both East and West, and not only with Buddhist philosophy, but also with other Eastern and Western philosophies.

Sri Lanka, with its long historical association with Theravada Buddhism for 23 centuries, has gained a name for Buddhist Studies. Thanks to its glorious past, the country has earned an international reputation as a center for Theravada Buddhist Studies. Even today, with departments at the major state universities, a postgraduate institute, and two separate universities all specializing in Buddhist Studies, the country may be described as providing many attractive opportunities for seekers of Buddhist knowledge. But this impressive picture of quantity does not seem to have an equally corresponding picture of quality.

I see two deficits in the present system of Buddhist Studies in the country. The first is that it is not sufficiently equipped with linguistic, philosophical, and logical tools for the study of Buddhism as a subject, even in a disinterested and objective manner. In other words, Buddhist Studies as an academic subject lags behind many other traditionally non-Buddhist countries which offer Buddhist Studies. If Buddhist Studies is to remain competitive, its practitioners in Sri Lanka must equip themselves with linguistic, logical, and philosophical tools to meet these other scholars on equal ground.

The second is that, in a historical context like Sri Lanka, Buddhist Studies cannot be reduced to just another academic subject among others. The philosophy found in it has guided humankind virtually all over the world for more than two millennia, and it has tremendous potential to continue to illuminate the way to a deluded world in the present and the future. What is needed, therefore, is not only factual or objective study but also interpretive studies, locating the philosophy of Buddhism in the context of human life in particular, and existence in general, including nature and the environment with all its forms of life. 
1. This article is an invited, non-peer reviewed contribution to the UCR.

2. Two Dhammapada stanzas make this point clear:

Though much he recites the sacred texts, but acts not accordingly, that heedless man is like a cowherd who counts others kine. He has no share in the fruits of the holy life.

Though little he recites the sacred texts, but acts in accordance with the teaching, forsaking lust, hatred and ignorance, truly knowing, with mind well freed, clinging to naught here and hereafter, he shares the fruits of the holy life. (Dhammapada 19, 20; translation adapted from Narada Thera, 1993.)

3. Samantapasadika I (Hewavitarana ed., p. 60). (2012). Buddhist Cultural Centre.

4. Anguttaranikaya-atthakatha, (Pali Text Society edition) p. 92.

5. For a detailed study of Valivita Saranankara Sangharaja refer Blackburn, A. M. (2001). Buddhist learning and textual practice in eighteenth century Lankan monastic culture. Princeton University Press.

6. It would not be out of place here to mention that T. W. Rhys Davids (1843-1922), who studied Pali from the Buddhist monks of Sri Lanka when he was serving in the Ceylon Civil Service from 1864 to 1872, and subsequently started the Pali Text Society in 1881, which still serves Buddhist Studies worldwide, was a beneficiary of this tradition.

7. Attributed to Richard H. Robinson in De Silva, M. W. P. (1971). Memorial tribute to the late Professor K. N. Jayatilleke. Philosophy East and West, 21(2), pp. 211-239.

8. With reforms introduced to the university system of the country in 1978, those that existed as campuses under the University of Sri Lanka were made independent and brought under the University Grants Commission (UGC) for financial and broader policy matters. Currently there are 15 universities under the UGC, largely determining their own curriculum. The two Buddhist universities come under the Ministry of Higher Education.

9. Pirivena in the Sinhala language means a monastic education center.

10. There are a few private higher academic institutes specializing in Buddhist Studies such as the Sri Lanka International Buddhist Academy (SIBA), Pallekelle, Kandy, and the Nagananda International Institute for Buddhist Studies, Manelwatta, Kelaniya, which are young in origin and have yet to establish themselves.

\section{References}

Adikaram, E. W. (2009). Early history of Buddhism in Ceylon. Buddhist Cultural Centre.

Blackburn, A. M. (2001). Buddhist learning and textual practice in eighteenth century Lankan monastic culture. Princeton University Press.

De Silva, M. W. P. (1971). Memorial tribute to the late Professor K. N. Jayatilleke. Philosophy East and West, 21(2), pp. 211-239.

Jayatilleke, K. N. (1963). Early Buddhist theory of knowledge. George Allen and Unwin. 
Jayatilleke, K. N. (2009). The contemporary relevance of the philosophy of the Buddha (Online ed.).

Buddhist Publication Society. https://www.bps.lk/olib/wh/wh258_Jayatilleke_ContemporaryRelevance-of-Buddhist-Philosophy.pdf (Original work published 1978)

Murti, T. R. V. (1956). The central philosophy of Buddhism. George Allen and Unwin.

Nanamoli, Bhikkhu. (1956). The path of purification. Semage Company.

Narada Thera. (1993). The Dhammapada: Pali text and translation with stories in brief \& notes. The Corporate Body of the Buddha Educational Foundation. 